Primljen / Received: 24.6.2016. Ispravljen / Corrected: 28.1.2017.

Prihvaćen / Accepted: 28.2.2017.

Dostupno online / Available online: 10.11.2017.

\section{Mechanical properties of mortar containing recycled asphalt}

Authors:

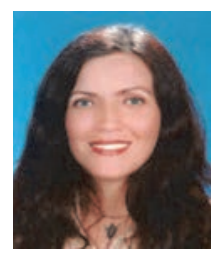

Assoc.Prof. Özlem Çelik Sola, PhD. CE Istanbul University, Turkey Faculty of Civil Engineering celik@istanbul.edu.tr

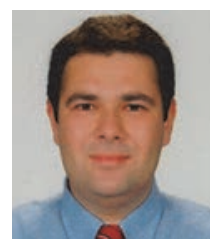

Assist.Prof. Cemil Ozyazgan, PhD. CE Affairs, Istanbul University, Istanbul, Turkey Department of Construction and Technical cemil.ozyazgan@kirklareli.edu.tr

\section{Özlem Çelik Sola, Cemil Ozyazgan}

\section{Mechanical properties of mortar containing recycled asphalt}

Recycled asphalt is used in this paper as replacement for a part of cement in the production of cement composite. A part of cement was replaced with a sieved recycled asphalt powder in the proportion of 5 to $15 \%$ of the cement weight. The testing comprised the analysis of density, Blaine specific surface area, setting time, particle size distribution, compressive strength, resistance to freezing and thawing, water absorption, and the SEM-EDS and XRD analyses. The results show that the density, compressive strength, and Blaine surface area decrease, and that toughness increases, with an addition of recycled asphalt into cement composite.

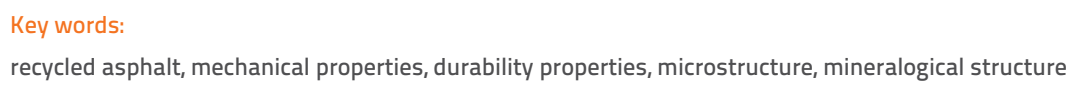

Stručni rad

\section{Özlem Çelik Sola, Cemil Ozyazgan}

\section{Mehanička svojstva morta s dodatkom recikliranog asfalta}

U radu je korišten reciklirani asfalt kao zamjena dijela cementa za pripremu cementnog kompozita. Dio cementa je zamijenjen prosijanim prahom od recikliranog asfalta $u$ omjeru od 5 do 15 \% na masu cementa. Ispitivanje je obuhvatilo analizu gustoće, Blainove specifične ploštine, vrijeme vezivanja, granulometrijski sastav, tlačnu čvrstoću, otpornost na smrzavanje i odmrzavanje, apsorpciju vode te SEM-EDS i XRD analize. Rezultati su pokazali da se dodatkom recikliranog asfalta u cementnom kompozitu smanjuje gustoća, tlačna čvrstoća i Blainova specifična ploština, a povećava se žilavost mješavina.

Ključne riječi:

reciklirani asfalt, mehanička svojstva, trajnosna svojstva, mikrostruktura, mineraloška struktura

Fachbericht

Özlem Çelik Sola, Cemil Ozyazgan

\section{Mechanische Eigenschaften von Mörtel mit Zugabe von wiederverwertetem Asphalt}

In der Untersuchung wurde wiederverwertetes Asphalt als Ersatz für Zementanteile bei der Herstellung von Kompositzement verwendet. Ein Teil des Zements wurde durch Pulver aus wiederverwerteten Asphalt im Verhältnis von 5 bis 15\% der Zementmasse ersetzt. Die Untersuchung umfasste eine Auswertung der Dichte, der massebezogenen Fläche nach Blaine, Bindezeit, granulometrischen Zusammensetzung, Druckfestigkeit, Frost- und Auftaufestigkeit, Wasserabsorption sowie eine SEM-EDS und XRD Analyse. Die Ergebnisse zeigten, dass durch Zugabe von wiederverwertetem Asphalt im Zementkomposit die Dichte, Druckfestigkeit und die massebezogene Fläche nach Blaine verringert werden, während die Zähigkeit der Mischungen ansteigt.

Schlüsselwörter:

wiederverwertetes Asphalt, mechanische Eigenschaften, Beständigkeit der Eigenschaften, Mikrostruktur, mineralogische Struktur 


\section{Introduction}

Recycling can be listed amongst the most attractive pavement rehabilitation options that have been available for many years. By taking into consideration regularly collected data, and the data on field and laboratory testing of recycled mixtures, it can be stated that recycling is expected to remain the most demanded technique in the future. When deciding which rehabilitation technique to use, attention should be paid to considerations such as energy conservation, economic aspects, engineering components, and environmental impacts [1]. Durable road pavements should be established by adopting solid construction and low maintenance solutions, given the fact that such expenses would have significant effects on national economy. Pavement engineering community is biased towards innovative approaches that incorporate ecologically friendly aspects. Reuse of waste materials, recycling of pavements in use, and various procedures developed under the warm mix method, which can possibly reduce environmentally hazardous gas emissions, are included in some specific eco-friendly techniques. In this respect, recycled materials have been increasingly used in Portland Cement Concrete (PCC) Pavements over the last couple of years [2]. Asphalt obtained through recycling process contains bitumen and is classified as a hazardous waste. However, its detrimental effects can be mitigated if used within the scope of a project.

Reuse of waste materials in form of recycled asphalt is an appropriate approach for construction practices that have recently been accepted by countries around the world. "All virgin" is the term used in Europe for defining asphalt mixtures containing less than $20 \%$ of recycled waste materials. The figures in the USA indicate that asphalt - $99 \%$ of re-use rate - remains at top when the use of recycled materials is considered. On the other hand, an average amount of recycled asphalt used in any mix design amounts to no more than $10-20 \%$. It can therefore be concluded that the proportion of asphalt obtained through recycling process can be used in mixtures more abundantly provided that the interaction of recycled materials and virgin materials is better determined and, consequently, better results can be obtained [3]. This study focuses on the effects the recycled asphalt has on the microstructure and mechanical properties of cementitious materials. As a matter of fact, a more profound study of mechanical properties necessitates the analysis of the aggregates to matrix interface. For this reason, special attention is placed on close correlation of microstructure and mechanical characteristics in order to improve the properties of material under investigation. Partial replacement of cement with recycled asphalt powder, at different aggregate grades and different ratios, is addressed in this study. The reliability and microstructural characteristics of reused asphalt powder with cement is also analysed.

\section{Experimental procedure}

\subsection{Materials used in this study}

Portland cement (CEM II/AL-LL 42.5 N) conforming to ASTM C150 was used. The recycled asphalt powder was produced by the Isfalt Company. The recycled asphalt powder filtered ranges of $0.425-$ $2 \mathrm{~mm}$ (A group), 0.18-0.425 mm (B group) and 0.075-0.18 mm (C group) sieves were used to produce cement composite in this study. The standard Rilem sand, with unit weight of $1.352 \mathrm{~kg} / \mathrm{m}^{3}$ and specific gravity of $2.563 \mathrm{~g} / \mathrm{cm}^{3}$, was used for preparing cement mortars.

\subsection{Mixture preparation and test methods}

The sand/cement/water ratio of 3/1/0.5 was used for all cement mortar mixtures. According to this ratio, $1350 \mathrm{~g}$ standard Rilem sand, $225 \mathrm{~g}$ water, and $450 \mathrm{~g}$ cement-recycled asphalt, were mixed to obtain all cement mortar mixtures. It can clearly be seen from mixing program that recycled asphalt was replaced with cement by mass of $5 \%, 10 \%$ and $15 \%$ respectively, to produce $4 \times 4 \times 16 \mathrm{~cm}$ specimens and obtain the optimal replacement value in the mixtures. The cement mortar mixtures used in the tests are presented in Table 1. A pycnometer test device (AccuPyc 1330 model) was used to

Table 1. Mixtures used in testing

\begin{tabular}{|c|c|c|c|c|c|c|c|}
\hline $\begin{array}{r}\text { composition } \\
\text { Mix ID }\end{array}$ & $\begin{array}{c}\text { Waste asphalt } \\
\text { percent } \\
{[\%]}\end{array}$ & $\begin{array}{c}\text { Cement } \\
\text { percent } \\
{[\%]}\end{array}$ & $\begin{array}{c}\text { Cement } \\
\text { qty. } \\
{[\mathrm{g}]}\end{array}$ & $\begin{array}{c}\text { Rilem } \\
\text { sand qty. } \\
{[\mathrm{g}]}\end{array}$ & $\begin{array}{c}\text { Waste asphalt } \\
\text { qty. } \\
{[\mathrm{g}]}\end{array}$ & $\begin{array}{c}\text { Water } \\
\text { qty. } \\
{[\mathrm{ml}]}\end{array}$ & $\begin{array}{c}\text { Sieve range of waste } \\
\text { asphalt } \\
{[\mathrm{mm}]}\end{array}$ \\
\hline Control & - & 100 & 450 & 1350 & - & 225 & - \\
\hline$\% 5$ A & 5 & 95 & 382,5 & 1350 & 67,5 & 225 & $0.425-2$ \\
\hline$\% 5$ B & 5 & 95 & 382,5 & 1350 & 67,5 & 225 & $0.180-0.425$ \\
\hline$\% 5$ C & 5 & 95 & 382,5 & 1350 & 67,5 & 225 & $0.075-0.180$ \\
\hline$\% 10$ A & 10 & 90 & 315 & 1350 & 135 & 225 & $0.425-2$ \\
\hline$\% 10$ B & 10 & 90 & 315 & 1350 & 135 & 225 & $0.180-0.425$ \\
\hline$\% 10$ C & 10 & 90 & 315 & 1350 & 135 & 225 & $0.075-0.180$ \\
\hline$\% 15$ A & 15 & 85 & 247,5 & 1350 & 202,5 & 225 & $0.425-2$ \\
\hline$\% 15$ B & 15 & 85 & 247,5 & 1350 & 205,5 & 225 & $0.180-0.425$ \\
\hline \%15 C & 15 & 85 & 247,5 & 1350 & 202,5 & 225 & $0.075-0.180$ \\
\hline
\end{tabular}


Table 2a. Chemical properties of the mixtures

\begin{tabular}{|c|c|c|c|c|c|c|c|c|c|c|}
\hline $\begin{array}{l}\text { Test } \\
\text { item }\end{array}$ & $\begin{array}{c}\text { Cement } \\
{[\%]}\end{array}$ & $\begin{array}{c}\% 5 A \\
{[\%]}\end{array}$ & $\begin{array}{c}\% 5 B \\
{[\%]}\end{array}$ & $\begin{array}{l}\% 5 C \\
{[\%]}\end{array}$ & $\begin{array}{c}\% 10 A \\
{[\%]}\end{array}$ & $\begin{array}{c}\% 10 \mathrm{~B} \\
{[\%]}\end{array}$ & $\begin{array}{c}\% 10 C \\
{[\%]}\end{array}$ & $\begin{array}{c}\% 15 A \\
{[\%]}\end{array}$ & $\begin{array}{c}\% 15 B \\
{[\%]}\end{array}$ & $\begin{array}{c}\% 15 \mathrm{C} \\
{[\%]}\end{array}$ \\
\hline $\mathrm{SiO}_{2}$ & 17.53 & 16.8 & 17.16 & 17.19 & 16.56 & 17.38 & 17.02 & 16.12 & 16.72 & 16.84 \\
\hline $\mathrm{Al}_{2} \mathrm{O}_{3}$ & 4.73 & 4.53 & 4.55 & 4.58 & 4.42 & 4.55 & 4.52 & 4.31 & 4.4 & 4.5 \\
\hline $\mathrm{Fe}_{2} \mathrm{O}_{3}$ & 2.08 & 1.99 & 2.04 & 2.04 & 1.96 & 1.99 & 2.02 & 1.92 & 1.97 & 1.97 \\
\hline $\mathrm{CaO}$ & 61.87 & 60.84 & 60.99 & 60.87 & 60.26 & 59.15 & 59.83 & 59.61 & 58.94 & 58.53 \\
\hline $\mathrm{MgO}$ & 1.16 & 1.35 & 1.24 & 1.25 & 1.32 & 1.37 & 1.35 & 1.38 & 1.42 & 1.46 \\
\hline $\mathrm{SO}_{3}$ & 3.42 & 3.07 & 3.12 & 3.3 & 2.77 & 2.49 & 2.79 & 2.21 & 2.48 & 2.85 \\
\hline $\mathrm{K}_{2} \mathrm{O}$ & 0.75 & 0.74 & 0.75 & 0.76 & 0.76 & 0.77 & 0.77 & 0.75 & 0.77 & 0.78 \\
\hline $\mathrm{Na}_{2} \mathrm{O}$ & 0.35 & 0.33 & 0.39 & 0.32 & 0.31 & 0.33 & 0.32 & 0.38 & 0.39 & 0.4 \\
\hline LOI & 8.38 & 10.44 & 9.83 & 9.8 & 11.42 & 11.43 & 11.24 & 13.18 & 12.78 & 12.67 \\
\hline
\end{tabular}

Table 2b. Physical properties of the mixtures

\begin{tabular}{|c|c|c|c|c|c|c|c|c|c|c|}
\hline $\begin{array}{l}\text { Test } \\
\text { item }\end{array}$ & $\begin{array}{c}\text { Cement } \\
{[\%]}\end{array}$ & $\begin{array}{c}\% 5 \mathrm{~A} \\
{[\%]}\end{array}$ & $\begin{array}{c}\% 5 \mathrm{~B} \\
{[\%]}\end{array}$ & $\begin{array}{c}\% 5 \mathrm{C} \\
{[\%]}\end{array}$ & $\begin{array}{c}\% 10 \mathrm{~A} \\
{[\%]}\end{array}$ & $\begin{array}{c}\% 10 \mathrm{~B} \\
{[\%]}\end{array}$ & $\begin{array}{c}\% 10 \mathrm{C} \\
{[\%]}\end{array}$ & $\begin{array}{c}\% 15 \mathrm{~A} \\
{[\%]}\end{array}$ & $\begin{array}{c}\% 15 \mathrm{~B} \\
{[\%]}\end{array}$ & $\begin{array}{c}\% 15 \mathrm{C} \\
{[\%]}\end{array}$ \\
\hline Blaine $\left[\mathrm{cm}^{2} / \mathrm{g}\right]$ & 4634 & 4226 & 4111 & 4435 & 3873 & 4080 & 4157 & 3793 & 3851 & 3937 \\
\hline Density $\left[\mathrm{g} / \mathrm{cm}^{3}\right]$ & 3.16 & 2.99 & 2.95 & 3.02 & 2.96 & 2.96 & 2.96 & 2.93 & 2.93 & 2.93 \\
\hline
\end{tabular}

determine density of cement mortar mixtures. According to this test method, the density of solid is obtained by measuring displacement of the gas passing through a solid sample. In this test method, the gas used should be an ideal gas such as helium and nitrogen. The Blaine test was also conducted for all cement mortar mixtures according to ASTM C204-11 using the air permeability method. Specific gravity of the sample is measured before the Blaine test. Then the time is measured for the constant quantity of air passing through the compacted sample bed at constant porosity and for the defined dimensions. Finally, the specific surface is estimated. Thus the Blaine surface area is obtained. Physical properties including the Blaine and density of all mixtures are given in Table 2. The initial- and final-setting times of the mortars were measured using the automatic Vicat test machine. The particle size distribution of the mixtures was measured using the Mastersizer laser device (Malvern model).

Compressive strength tests were conducted for all mortar mixtures at 2 , $7,28,56$, and 98 days using $4 \times 4 \times 16 \mathrm{~cm}$ specimens. To obtain the compressive strength test results, the loading rate of $0.5 \mathrm{MPa} / \mathrm{s}$ was selected as constant in all tests. The specimens were cured at three different conditions. In this study, the 98-day normal curing in water was called X-Series. The solution including 13 $\%$ of $\mathrm{MgSO}_{4}$ by mass was used to conduct the freezing-thawing test. This test was conducted according to ASTM C-666. In order to observe the freezing-thawing properties of the mixtures, including the 98-day curing after the mixtures were kept in the solution for one week, the mixtures were dried in an oven at $105^{\circ} \mathrm{C}$ for one week. This process was assumed to be one circle, and four circles were applied for each mixtures. This method was called Y-series in this study. On the other hand, the wetting-drying tests were applied to all mixtures. The mixtures were kept in the water curing tank for one week. These mixtures were then removed from the tank and dried in air conditions for one week. This process was assumed to be one circle, and four circles were applied for each mixture. This method was called Z-series in this study.

The weight loss of mixtures obtained by $X, Y$ and $Z$ series, as mentioned above, was determined for each cycle. The weight change calculations were made according to following formula, equation (1).
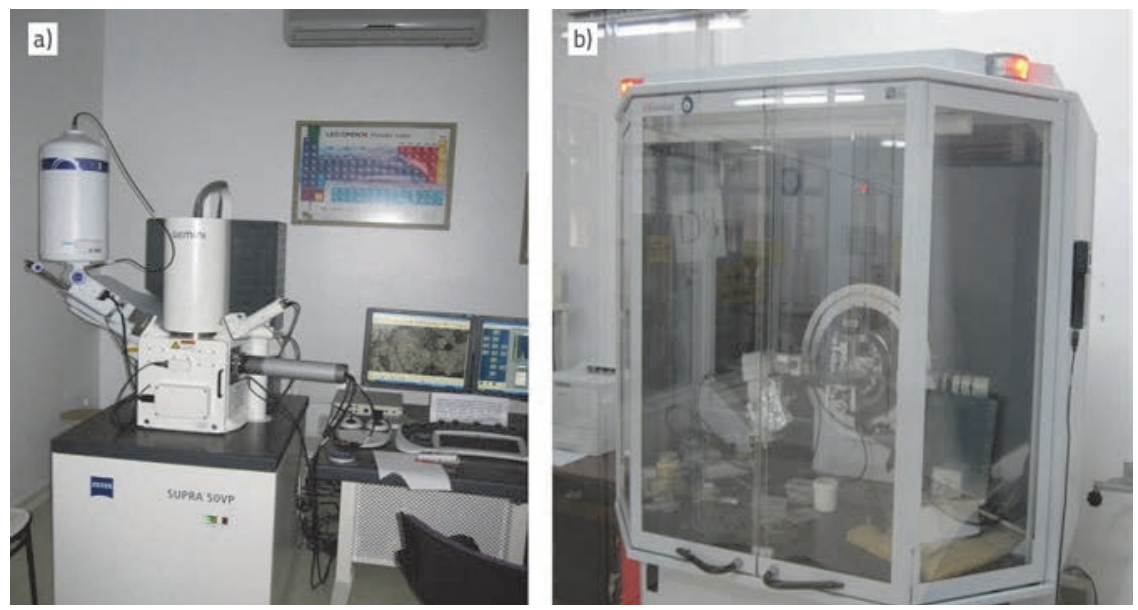

Figure 1. a) SEM-EDS test machine; b) XRD test machine 
$W_{D}=\left(W_{t}-W_{0}\right) / W_{0} \times 100$

where:

$W_{D}$ - weight change $[g], W_{t}$ - weight at time $t, W_{0}$ - initial weight.

Zeiss marked and Supra $50 \mathrm{~V}$ model Scanning Electron Microscope (SEM-EDS) device was used in order to observe the micro structure of the mixtures used in the test (Figure 1.a). While the samples were being prepared, care was taken to take samples from the homogenous part of the mixture. The sample was covered with gold/palladium to protect it from electron scattering. The X-ray diffraction method (XRD) is a usual method for determining characteristic properties of crystalline materials. $X$-rays, which are sent to the sample, are diffracted by the plane on the sample at different angles according to Bragg Law. The results obtained from this method are like a fingerprint for each phase. These are used for finding the phases in the sample. The XRD analysis of mixtures was conducted by using th eXRD test machine, i.e. a Bruker marked and D8 Advance model (Figure1.b).

\section{Test results and discussions}

\subsection{Physical Properties}

The density is influenced by the addition of recycled asphalt in the mixtures. Table 2 shows the density of mixtures mixed with different percentages and particle sizes of recycled asphalt. It was established that the density of the mixtures decreases with an increase in percentage of recycled asphalt. This is due to the fact that the recycled asphalt has low unit weight, and so the recycled asphalt mixtures will also have low density. In this study, the Blaine values of the mixtures decrease with an increase in the quantity of recycled asphalt. The highest value was observed in sample $\% 5 \mathrm{C}\left(4634 \mathrm{~cm}^{2} / \mathrm{g}\right)$. On the other hand, the lowest one was observed in Mix ID of sample \%15A (15\% of recycled asphalt and 0.425-2 mm sieve range, Blaine: $3793 \mathrm{~cm}^{2} / g$ ). All Blaine values of the mixtures are shown in Table 2.

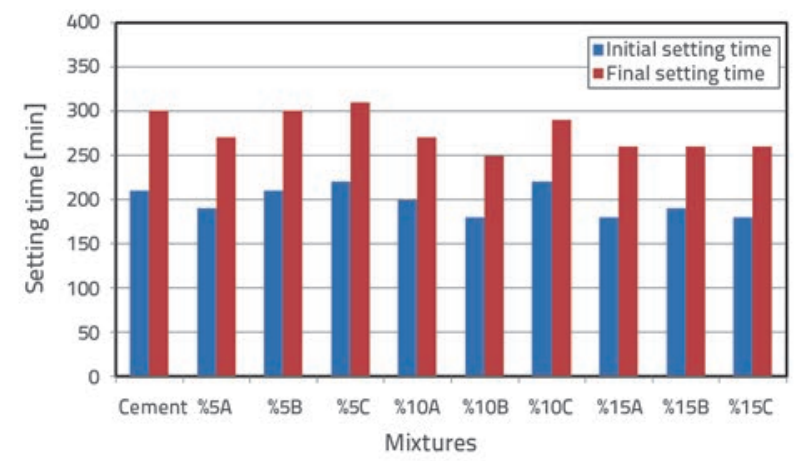

Figure 2. Initial and final setting times of mixtures

Initial- and final-setting times of the mixtures are shown in Figure 2. According to this figure, the initial- and final-setting times of the control sample are 210 and 300 minutes, respectively. The lowest initial setting times were observed in samples $\% 10 \mathrm{~B}, \% 15 \mathrm{~A}$ and $\% 15 \mathrm{C}$ (180 minutes). On the other hand, the highest initial setting times were observed in samples $\% 5 C$ and $\% 10 C$ (220 minutes). Particle size distributions of mixtures used in lab testing are presented in Figure 3. According to this figure, the cement used in the test is finer compared to other mixes. The fineness properties of the mixtures change from $A(0.425-2 \mathrm{~mm}$ sieve) to $\mathrm{C}(0.075-0.180$ $\mathrm{mm}$ sieve). As can be seen in Figure 3 , an increase in the amount of recycled asphalt generally results in the decrease in fineness of the mixtures. As the cement is finer than the recycled asphalt used in the test, an addition of recycled asphalt to the mixtures changes the fineness of the composites.

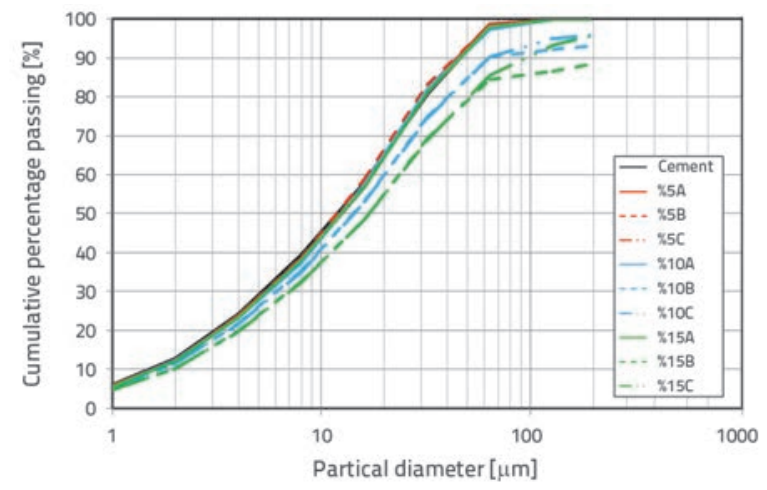

Figure 3 Particle size distributions of mixtures used in testing

\subsection{Compressive strength results}

The compressive strength test results with respect to $2,7,28,56$, and 98 days of curing time are given in Figure 4. $X$ series indicates that the mixtures used in the test are normally cured for 98 days. The results show that compressive strength values of all mixtures with recycled asphalt are lower compared to the control sample. This indicates that the strength of the mixtures decreases with an increase in the proportion of recycled asphalt in the composites. Moreover, compressive strength properties of the mixtures are affected by particle size of recycled asphalt.

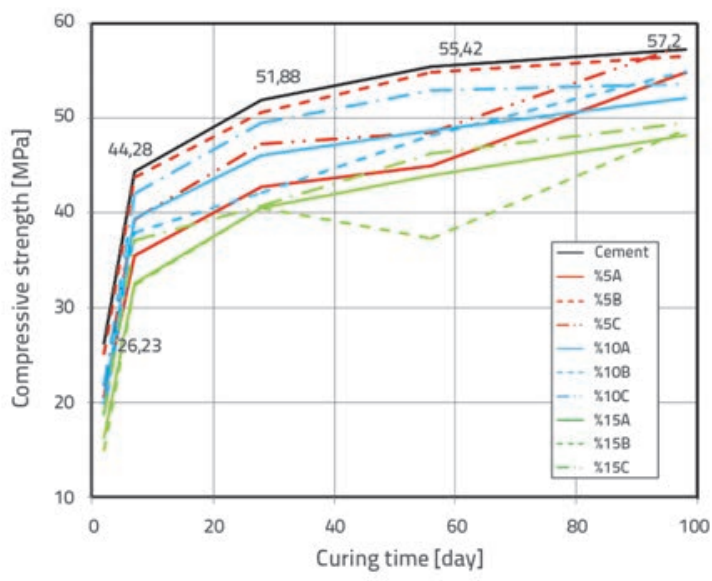

Figure 4. Compressive strength results of mixtures with respect to curing time

Compressive strength test results for $X, Y$ and $Z$ series with different quantities of recycled asphalt are shown in Figure 5 . It can clearly 
be seen in Figure 5 that the compressive strength of the mixtures prepared in $Y$-series is lower compared to $X$ and $Z$ series for $\% 5 A$, $\% 5 \mathrm{~B}$ and control mixtures. However, compressive strength values of mortars prepared in Y-series are higher than the corresponding values for $X$ and $Z$ series. The highest compressive strength results of the mortars are generally observed in control samples compared to other mixtures. Furthermore, the compressive strength of the samples obtained by the wetting-drying method (Y-series) has closer results to the samples obtained by the normal curing method (X-series), except for the control mix.

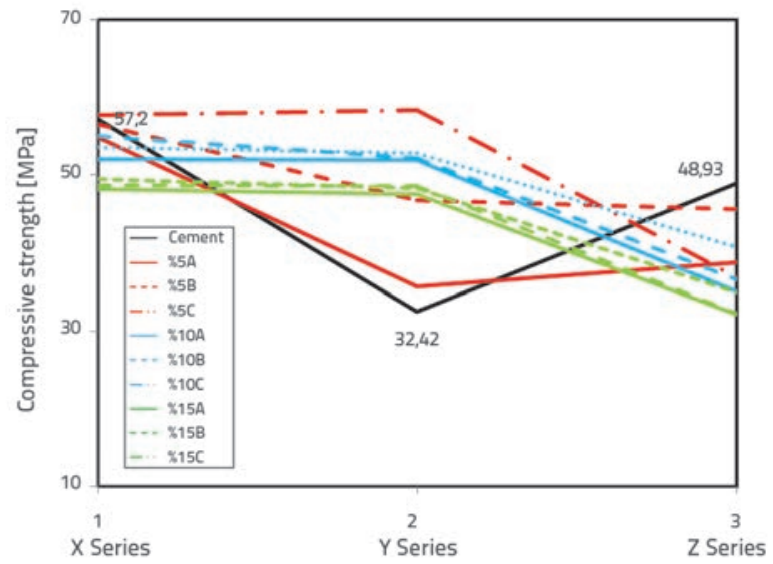

Figure 5. Compressive strength results of mixtures with respect to $X$ $\mathrm{Y}$ and $\mathrm{Z}$ series

\subsection{Durability test results}

The weight change analyses of samples obtained by durability testing for $Y$ and $Z$ series were conducted in this study, as shown in Figure 6 and Figure 7.

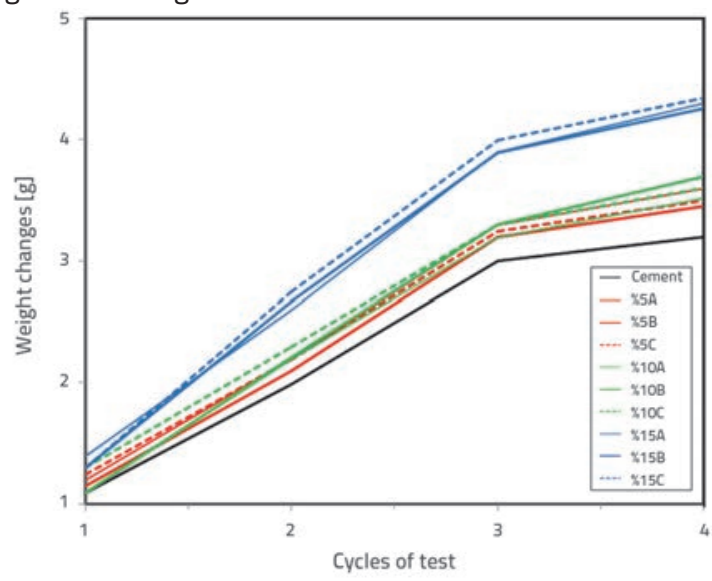

Figure 6. Weight changes with respect to test cycles for Y-series

The weight changes of the mixtures for $Y$ series are higher than the corresponding changes for the control mixture. In other words, they are able to absorb more water. This can be explained by the inability of waste asphalt to fill voids to the extent exhibited by mineral additive. Recycled asphalt is a petroleum material and it has a low adherence to cement. On the other hand, magnesium sulphate $\left(\mathrm{MgSO}_{4}\right)$ starts to show a destruction effect on cement mortar after six months. Therefore, this situation has not as yet been observed. Namely, no reduction was observed in weight change of the mixtures, and the acceleration of weight change started to decrease after the third cycle for $Y$ series. However, the change in weight was observed after the third cycle for $Z$ series. Because of that the hydration product was dissolved, and weight loss started to occur. This loss for $Z$ series is higher compared to $Y$ series.

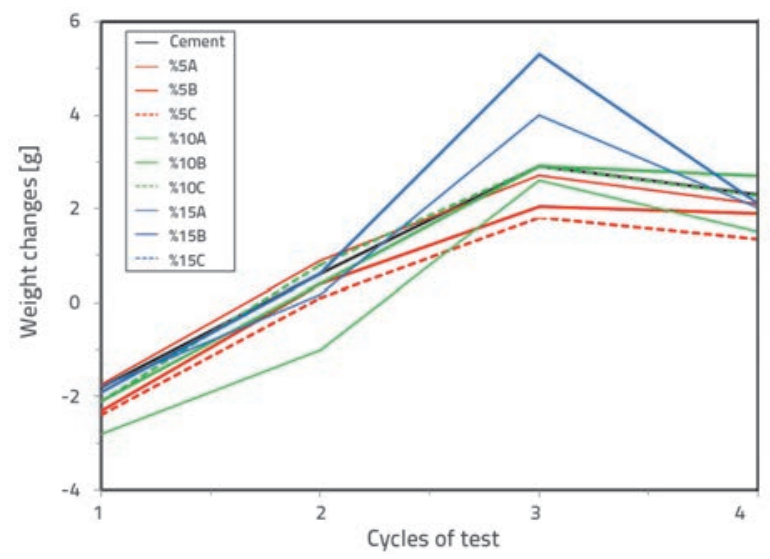

Figure 7. Weight changes with respect to test cycles for Z-series

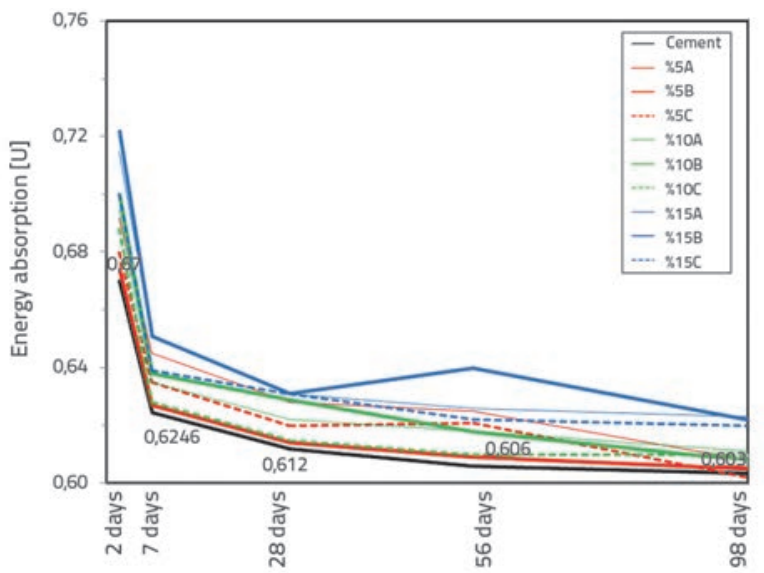

Figure 8. Energy absorption capacity of mixtures with respect to their curing time

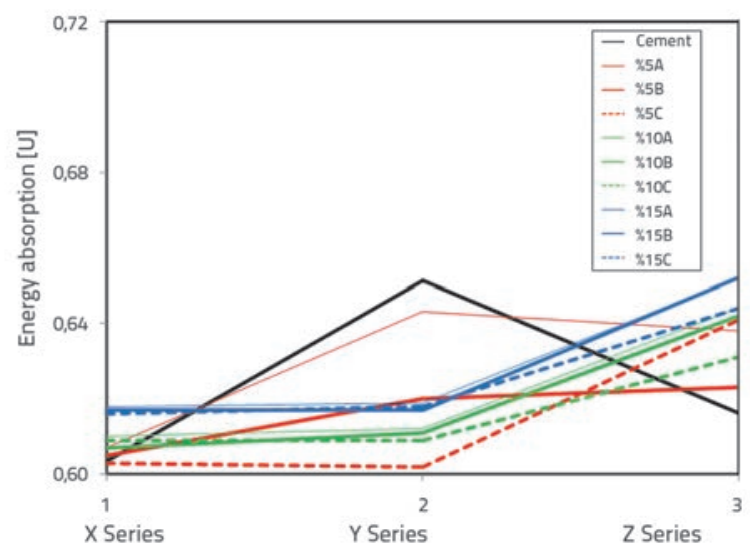

Figure 9. Energy absorption capacity of mixtures with respect to $X, Y$ and $Z$ series 
Toughness, known as energy absorption capacity, is generally de $\phi \lambda$ ned as the area under load deflection curve of a flexural specimen [4]. The toughness values of all mixtures used in the test were calculated and presented in Figure 8 and Figure 9. According to Figure 8, the toughness of the samples including recycled asphalt are greater than that of the control sample.
The toughness increases with an increase in recycled asphalt proportion in cement paste. As can be seen in Figure 9, the toughness of the samples containing $\% 5 \mathrm{~A}$ and $\% 5 \mathrm{~B}$ recycled asphalt is similar to that of the control sample. However, the toughness of other samples reveals different behaviour. Especially, the toughness of the samples containing \%5A and

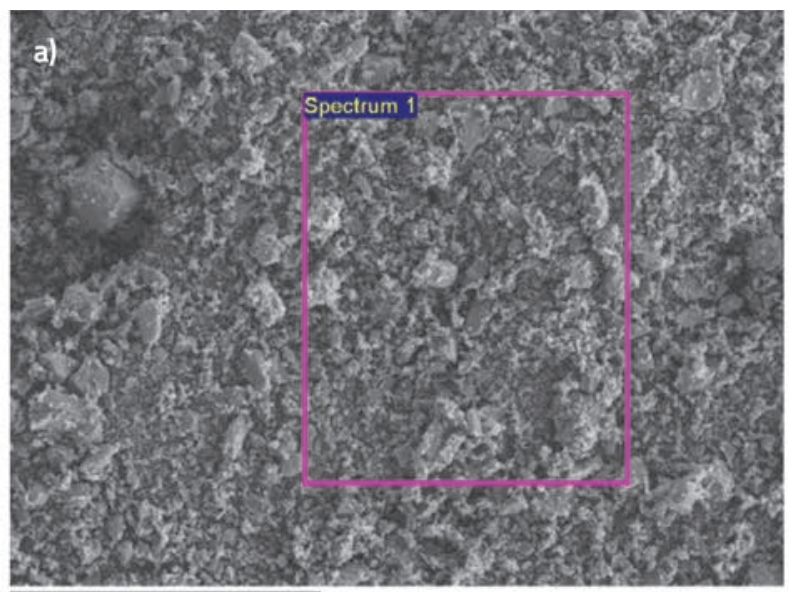

$300 \mu \mathrm{m}$

Electron image 1

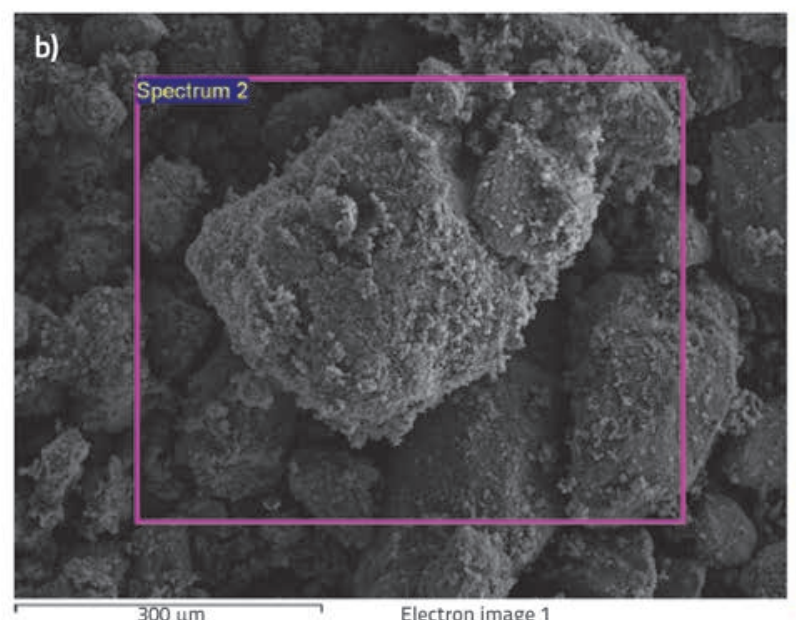

Electron image 1
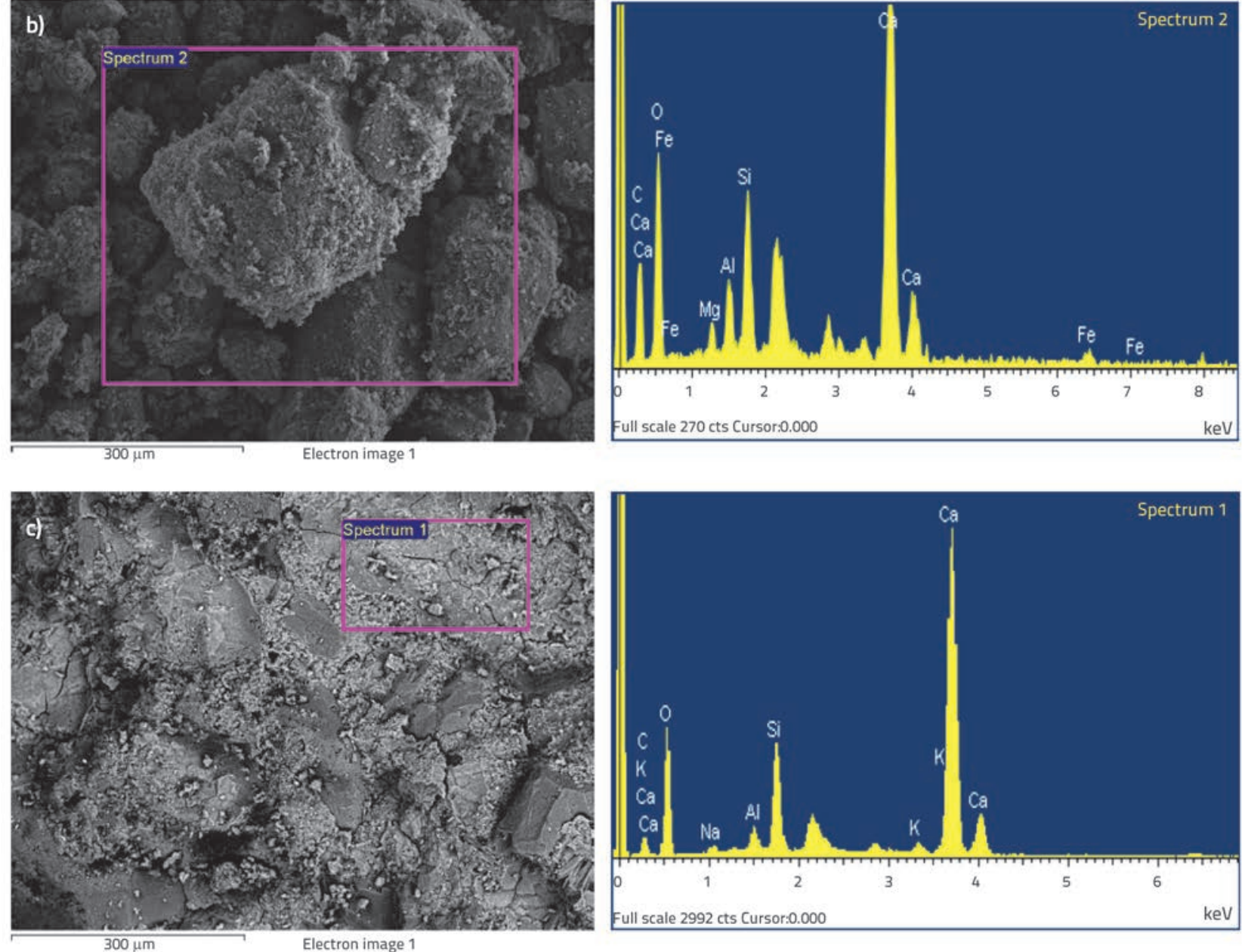

Eull scale 270 cts Cursor:0.000

keV

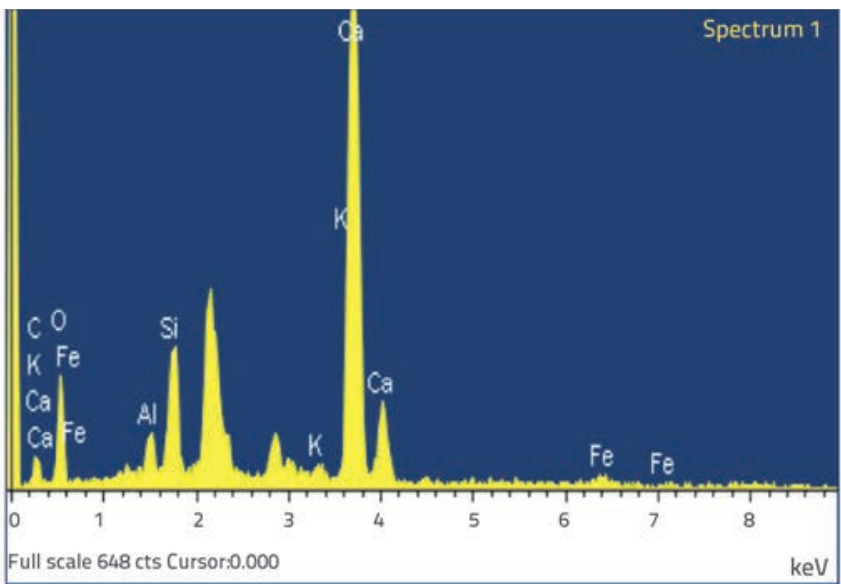

keV

Figure 10. SEM-EDS analysis of samples: a) cement; b) asphalt waste;. c) $\% 10 C$ mixture for 28 day curing time 
$\% 5 B$ recycled asphalt obtained from freezing-thawing cycles ( $Y$-series) is greater compared to $X$ and $Z$ series. On the other hand, the toughness of other samples obtained from freezingthawing cycles ( $Y$-series) is lower than that registered in $X$ and $Z$ series. Therefore, it can clearly be seen from results that the addition of $\% 5 \mathrm{~A}$ and $\% 5 \mathrm{~B}$ recycled asphalt to cement mortar mixture is a critical point for freezing-thawing cycles (Y-series).

\subsection{Microstructure and mineralogical analysis of mixtures}

The microstructure and mineralogical analysis of the cement, recycled asphalt and the mixtures (prepared with group C) were conducted using the SEM and XRD methods. The reason for selecting group $\mathrm{C}$ is related to the compressive strength of the mixtures. Microstructure views of cement, recycled asphalt and mixture, with respect to $\% 10 \mathrm{C}$ for 28 day curing time used in the test, are shown in Figure 10. When the views belonging to the cement and recycled asphalt were scaled up with 150X, a case close to homogeneous one was observed. On the other hand, when the views were scaled up with $2000 \mathrm{X}$, the spherical and non-spherical sample structures became apparent. Calcium (Ca), as the most represented component in cement sample, gives a peak value at different points with respect to other elements (Figure10-a).The microstructure view of recycled asphalt reveals various types of structures. The recycled asphalt of irregular shape and size notwithstanding fibrous structures can clearly be observed (Figure10.b). These results are repetitive for chemical analysis. The microstructure view of the mixture with respect to $\% 10 \mathrm{C}$ is shown in Figure10-c. According to this figure, quartz structures are situated in a slightly grey region. The calcium-silicate structure can easily be observed from the view. However, C-S-H gels in $\% 10 C$-mixture for 28 day curing time were not observed from the views. Two major peaks of $\mathrm{Ca}$ and Si were identified through EDS analyses. An abundance of Ca peaks can be observed in Figure 10. This is due to mortar asphalt powder that contains $\mathrm{CaCO}_{3}$. The $\mathrm{X}$-ray diffraction pattern leads to a quantitative finding of hydration products and provides an opportunity to determine a mineral phase of chemical materials [5]. XRD results for the control mixture and the $\% 10 \mathrm{C}$ mixture were obtained using the X-ray diffraction method, as shown in Figure 11. XRD results were obtained at 28, 56 and 98 days of curing (for $\mathrm{X}, \mathrm{Y}$ and $\mathrm{Z}$ series). $\mathrm{C}-\mathrm{H}$ consuming results for the samples are directly compatible with the compressive strength test results of the samples. Namely, an increase in $\mathrm{C}-\mathrm{H}$ consuming brings about an increase in compressive strength. The $\mathrm{X}$-ray powder diffraction patterns of mortar with recycled asphalt points to the presence of calcium carbonate as calcite $\left(\mathrm{CaCO}_{3}\right)$ and quartz, predominantly. In fact, there are some carbonate additions in hydration products. Accordingly, the $\mathrm{CaCO}_{3}$ phase was determined as a conclusion of secondary reactions in mortar with recycled asphalt [5].
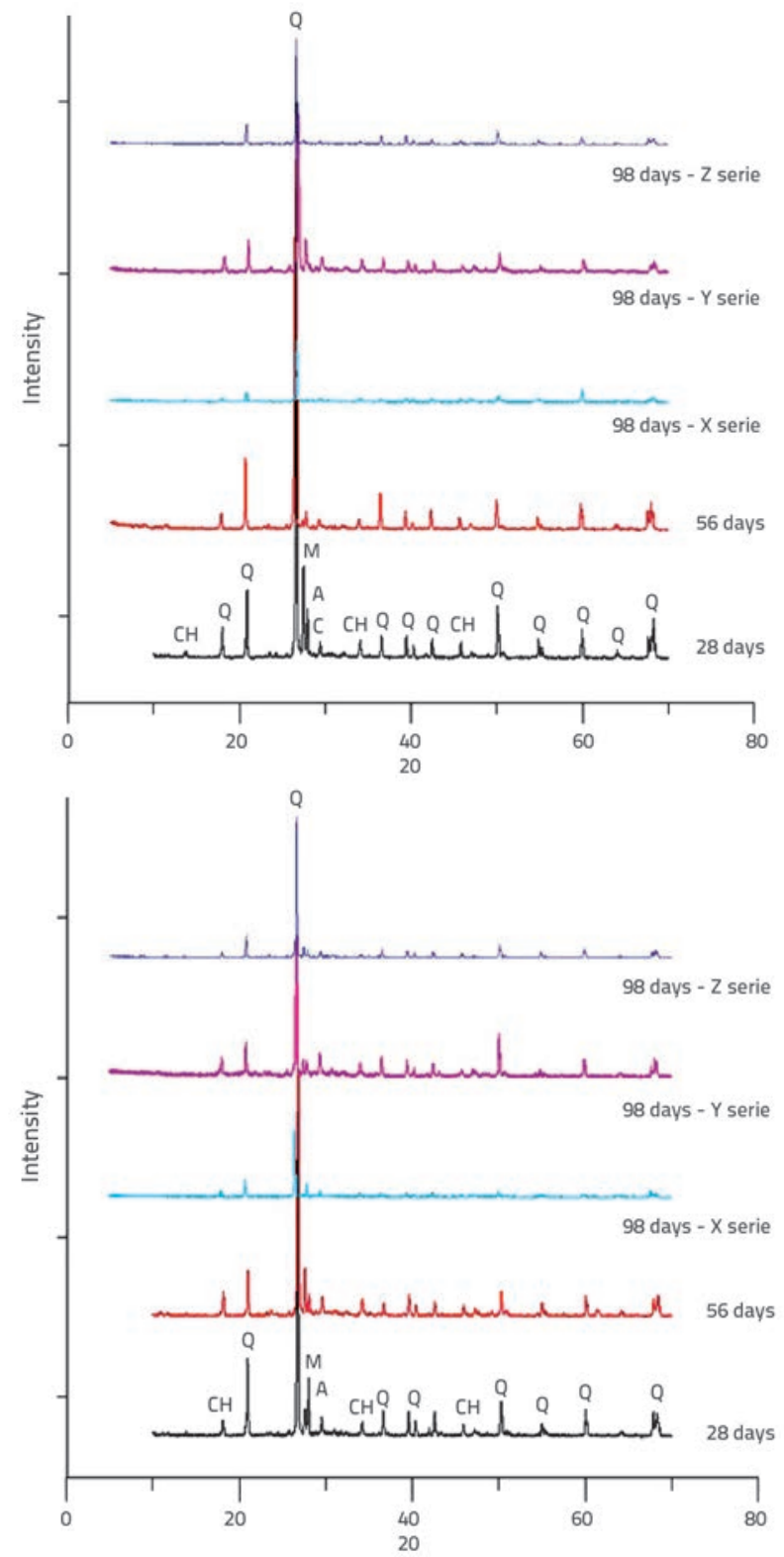

Figure 11. XRD analysis of samples: a) control sample; b) $\% 10 \mathrm{C}$ mixture sample

\section{Conclusion}

The density is influenced by the addition of recycled asphalt in the mortar. The density of the mixtures considered in this study decreases with an increase in the percentage of recycled asphalt. The Blaine values of the mixtures decrease with an increase in the quantity of recycled asphalt. The highest value is observed at sample $\% 5 \mathrm{C}\left(4634 \mathrm{~cm}^{2} / \mathrm{g}\right)$. On the other hand, the lowest one is observed in Mix ID of \%15A (15\% of recycled asphalt, sieve range: $0.425-2 \mathrm{~mm}$, Blaine: $3793 \mathrm{~cm}^{2} / \mathrm{g}$ ). Higher proportion of recycled asphalt in the mixtures changes the initial- and final-setting time of mortars. An increased 
quantity of recycled asphalt generally decreases the fineness of the mixtures. The fineness properties of the mixtures change from A (sieve size: $0.425-2 \mathrm{~mm}$ ) to C (sieve size: 0.075-0.180 $\mathrm{mm})$. Compressive strength values of mortars prepared using mixtures with recycled asphalt are lower than those of the control sample. A higher proportion of recycled asphalt in the composites decreases the compressive strength of the mortars. Particle size of the recycled asphalt changes strength properties of the mortars. The compressive strength of the mortars prepared in $Y$-series is lower than $X$ and $Z$ series for $\% 5 A$, \% $5 \mathrm{~B}$ and control mortar. The compressive strength of samples treated by the wetting-drying method (Z-series) is nearest to the samples obtained from the normal curing method (X-series) for all test results.

\section{REFERENCES}

[1] Sengoz, B., Oylumluoglu, J.: Utilization of recycled asphalt concrete with different warm mix asphalt additives prepared with different penetration grades bitumen, Construction and Building Materials, 45 (2013), pp.173-183, https://doi.org/10.1016/j. conbuildmat.2013.03.097

[2] Modarres, A., Hosseini, Z.: Mechanical properties of roller compacted concrete containing rice husk ash with original and recycled asphalt pavement material, Materials and Design, 64 (2014), pp.227-236, https://doi.org/10.1016/j. matdes.2014.07.072

[3] Rinaldini, E., Schuetz, P., Partl, M.N., Tebaldi, G., Poulikakos, L.D.: Investigating the blending of reclaimed asphalt with virgin materials using rheology, electron microscopy and computer tomography, Composites: Part B., 67 (2014), pp.579-587, https:// doi.org/10.1016/j.compositesb.2014.07.025
No reduction was observed in weight change of the mortars and the acceleration of weight change started to decrease after the third cycle for $Y$ series. The toughness of the samples with recycled asphalt is greater than that of the control sample. The toughness of mortars increases with an increase in the recycled asphalt proportion in cement paste. The micro-structure view of recycled asphalt reveals different types of structures. The recycled asphalt of irregular shape and size notwithstanding fibrous structures can clearly be observed. C-S-H gels in $\% 10 C$-mixture for 28 day curing time were not observed from the views. $\mathrm{C}-\mathrm{H}$ consumption of the samples is directly compatible with the compressive strength test results of the samples. The compressive strength increases with an increase in $\mathrm{C}-\mathrm{H}$ consumption.

[4] Tantala, M.W., Lepore, J.A., Zandi, I.: Quasi-elastic behavior of rubber included concrete.In: Ronald Mersky (Ed.), Proceedings of the $12^{\text {th }}$ International Conference on Solid Waste Technology and Management, Philadelphia, PA, 1996.

[5] Turkin, M., Bretagne, E., Rouis, M.J., Quéneudec, M.: Microstructure, physical and mechanical properties of mortarrubber aggregates mixtures, Construction and Building Materials, 23 (2009), pp.2715-2722, https://doi.org/10.1016/j. conbuildmat.2008.12.019 